\title{
PLURALITAS AGAMA MENURUT PANDANGAN TOKOH-TOKOH AGAMA DAYAK DI DESA KAPUL KECAMATAN HALONG KABUPATEN BALANGAN
}

\author{
Abdul Hamid \\ Mahasiswa Magister (S2) Prodi Agama dan Filsafat Islam Konsentrasi Agama dan Resolusi \\ Konflik Fakultas Ushuluddin dan Pemikiran Islam UIN Sunan Kalijaga
}

Diterima tanggal 25 April 2017 / Disetujui tanggal 13 Juni 2017

\begin{abstract}
Religious plurality is condition which no one can reject it but it must be thought how to respond the issue. So far, many recorded attitude show various respond about it. This work will elaborate the issue from religious people's perspective, especially the figures in Kapul village, Halong districts of Balangan regency. Actually, it is Dayak's region. But, there are many religious followers such Islam, Catholics, Hinduism, Buddhism, and local religion. They live together in harmony. This research is a qualitative one with sociological approach as the main theory of Max Weber's charismatic. While the methods are direct observation, interview, and documentation.It concluded that Dayak figures believe that everyone can choose their religion without force and pressure so then they can respect another highly. Even in the village, every community will attend an event that hold by other religious communities. They believe that all of them are originated from the same ancestor so religion cannot change this principle.
\end{abstract}

Kata kunci: Pluralitas agama, tokoh agama, Dayak

\section{Pendahuluan}

Indonesia merupakan negara yang sangat beragam dari daratan Sabang sampai Merauke, dari Miangas hingga Pulau Rote terdiri atas beragam etnis, bahasa, budaya, adat istiadat, maupun agamanya.Dengan kata lain, bangsa Indonesia memiliki potensi, watak, karakter, hobi, tingkat pendidikan, warna kulit, status ekonomi, kelas sosial, pangkat dan kedudukan, cita-cita, perspektif, orientasi hidup, loyalitas organisasi, kecenderungan dan afiliasi ideologis yang berbeda-beda. Dari segi kultural maupun struktural, fenomena tersebut mencerminkan adanya tingkat keragaman yang tinggi. ${ }^{1}$ Kemajemukan bangsa Indonesia, juga disebabkan karena hampir semua agama-agama besar, yakni Islam, Kristen Protestan, Katholik, Hindu Budha dan Konghucu ada di negeri ini. ${ }^{2}$ Oleh sebab itu, jika pluralitas agama tidak dipahami secara benar dan arif oleh masing-masing pemeluk agama, akan menimbulkan konflik, baik konflik antarumat beragama, konflik sosial,bahkan merambah pada isu disintegrasi bangsa. ${ }^{3}$

${ }^{1}$ M. Muslich dan Adnan Qohar, Nilai Universal Agama-Agama Di Indonesia: Munuju Indonesia Damai (Yogyakarta: Kaukaba, 2013), 5.

${ }^{2}$ Umi Sumbulah dan Nurjannah, Pluralisme Agama Makna dan Lokalitas Pola Kerukunan Antarumat Beragama (Malang: UIN Maliki Press, 2013), 1-2.

${ }^{3}$ M. Zainuddin, Pluralisme Agama Pergulatan Dialogis Islam-Kristen di Indonesia, 1-2. 
Di era demokrasi dan globalisasi, pluralitas kemudian menjadi isu penting dan sering disosialisasikan. Hal ini dilakukan dengan harapan ketika semangat pluralitas dalam beragama dipahami dengan baik, ketegangan dan konflik yang disebabkan oleh isu agama dapat diredam, atau paling tidak makin berkurang. ${ }^{4}$

Dalam kamus "The Random House Dictionary of the English Language” kata 'plural' antara lain diartikan "pertaining or involving a plurality of persons or things" (berkenaan atau melibatkan banyak orang atau hal). Kata pluralisme bisa juga diartikan "a theory thatreality consists of two or more independent elements" (suatu teori bahwa realitas terdiri dari dua unsur independen atau lebih), kata plurality (pluralitas) diartikan state or fact of being plural" (keadaan atau fakta yang bercorak majemuk). ${ }^{5}$ Jadi pluralisme agama adalah kondisi hidup bersama antar agama yang berbeda-beda dalam satu komunitas dengan tetap mempertahankan ciri-ciri spesifik atau ajaran masing-masing agama. ${ }^{6}$

Disinilah harus diatakan bahwa pluralitas adalah sebuah keniscayaan dan kehendak Tuhan yang tidak bisa dingkari. Konsekuensi dari pernyataan ini adalah keniscayaan masing-masing pemeluk agama bersikap penuh toleran terhadap orang lain yang berbeda keyakinan atau agama, apapun namanya. Penolakan terhadap pluralitas bisa dipandang sama dengan penolakan terhadap realitas sekaligus menolak kehendak Tuhan Yang Maha Bijaksana.

Pluralitas agama dapat membawa konsekuensi pada perbedaan-perbedaan dan batas-batas kelompok sosial. Ketika bersinggungan dengan faktor-faktor lain, perbedan-perbedaan dan batas-batas kelompok sosial ini akan semakin dipertegas sehingga pemahaman terhadap orang lain akan lebih didasarkan pada sterotip dan prasangka. Hubungan ini tentu akan mudah memicu munculnya keteganganketegangan dan konflik. ${ }^{8}$

Hal ini yang bisa terjadi terhadap keberagamaan masyarakat di Desa Kapul Kecamatan Halong Kabupaten Balangan. Karena di daerah ini memiliki agama yang berbeda-beda seperti agama, Islam, Kristen, Katolik, Hindu, Budha, dan agama lokal. ${ }^{9}$ Meskipun mereka hidup dalam lingkungan yang memiliki berbagai macammacam agama, bahkan ada yang dalam satu rumah berbeda agama, ada yang beragama Islam, Hindu, Budha dan Kristen, dan agama lokal, mereka bisa hidup rukun dan damai walaupun terkadang ada konflik kecil di antara mereka, tetapi masih bisa diselesaikan dengan sistem kekeluargaan melalui bantuan tokoh-tokoh agama

${ }^{4}$ M. Nur Kholis Setiawan dan Djaka Soetap, Meniti Kalam Kerukunan, Jakarta: PT BPK Gunung Mulia, 2010), 8.

${ }^{5}$ Faisal Ismail, Dinamika Kerukunan Antarumat Beragama, (Bandung: PT Remaja Rosdakarya, 2014), 17.

${ }^{6}$ Anis Malik Thoha, Tren Pluralisme Agama Tinjanan Kritis, (Jakarta: Perspektif, 2005), 14. 13.

${ }^{7}$ Husein Muhammad, Mengaji Pluralisme Kepada Mabaguru Pencerahan, (Bandung: Mizan, 2011),

${ }^{8}$ Mustain, Fawaizul Umam, Pluralisme Pendidikan Agama Hubungan Muslim-Hindu di Lombok, (Mataram: LKM IAIN Mataram, 2005), 91.

${ }^{9}$ Kementerian Agama Data Penganut Agama Kabupaten Balangan akhir tahun 2015. 
Dayak (Balian) yang dianggap memiliki kekuasaan dalam hal keagamaan dan ritual adat istiadat.

Dalam kajian ini, penulis mengunakan metode penelitian lapangan (field research)langsung terjun kelapangan melakukan observasi, melalui wawancara langsung dengan tokoh-tokoh agama Dayak di Desa Kapul Kecamatan Halong.Pendekatan yangdigunakan dalam penelitian iniadalah teori sosiologi kharismatik Max Weber. Dalam penelitian ini penulis berusaha untuk melihat konsep kharismatik yang terdapat di dalam diri tokoh-tokoh agama Dayak di Desa Kapul Kecamatan Halong Kabupaten Balangan dalam upaya menerima pluralitas agama yang ada di tempat tinggalnya, sehingga pluralitas agama yang ada di desa Kapul ini tidak menjadikan pemeluk agama Dayak dengan pemeluk agama lain sebagai masyarakat yang intoleransi.

\section{Mengenal Teori Kharismatik Max Weber}

Membaca definisi Weber yang sering dikutip tentang kharismatik yaitu sebagai berikut, suatu sifat dari sesuatu kepribadian yang berbeda dari orang biasa dan diperlakukan seolah-olah diberkati daengan kekuatan-kekuatan gaib, melebihi tenaga manusia, atau setidak-tidaknya dengan kekuatan-kekuatan atau kecakapan yang luar biasa. Titik beratnya terletak bukan pada siapa pemipin tersebut, tetapi bagaimana iya ditanggapi oleh mereka yang di bawah kekuasaannya dan inilah yang menentukan berlakunya kharisma tersebut. Kharismanya terkandung pada persepsipersepsi rakyat yang dipimpinnya. ${ }^{10}$

Dalam bahasa Inggris "charisma"; power or talent given by God, charismatic; emphasizing the divine gifts. Kharisma adalah pemberian Tuhan. Kharismatik adalah sifat seorang figur yang mempunyai kharisma dan merupakan pemberian Tuhan. Dalam bahasa Indonesia dijelaskan bahwa kharisma adalah keadaan atau bakat yang dihubungkan dengan kemampuan yang luar biasa dalam hal kepemimpinan yang didasarkan atas kualitas kepribadian individu. Kharisma merupakan karunia Roh Kudus yang luar biasa yang diberikan kepada orang beriman supaya melayani umat.

Kata kharisma dari bahasa Yunani berasal dari Perjanjian Baru, charisma, pemberian Tuhan, yang dikenal oleh dunia terutama masyarakat primitive dinamakan mana dan dari pengertian ini termasuk kharisma. Dalam bahasa Persia bvarnah yang berarti mulia atau agung.Bagi orang Persia dan Yunani, kharisma berarti sebuah pemberian para dewa yang dihadiahkan kepada seseorang.Menurut Weber:

Charisma will be applied ti a certain quality of an individual personality by virtue of wich is set apart from ordinary men and treated as endowed with supernatural, superhuman, or at least specifically exceptional powers or qualities. These are such as are not accessible to the ordinary person but are

\footnotetext{
${ }^{10}$ Sartono Kartodirdjo, Kepemimpinan Dalam Dimensi Sosial, ( Jakarta: LP3ES, 1986),
} 165-167. 
regarded as of a divine origin or as exemplary, and on the basis of them the individual concerned is treated as a leader.

Istilah kharisma digunakan terhadap sifat tertentu pada seseorang yang karenanya orang tersebut dibedakan dengan orang biasa dan dipandang mendapat kekuatan adikodrati, adimanusiawi atau paling tidak luar biasa kekuatannya sedemikian rupa sehingga tidak terjangkau oleh orang biasa tetapi dianggap sebagai/berasal dari Tuhan, atau sebagai teladan dan atas dasar itu individu tersebut diperlakukan sebagai seorang pemimpin. ${ }^{11}$

Kharismatik adalah sifat seseorang yang mempunyai kharisma, mempunyai kualitas tertentu bagi seorang individu yang menyebabkan dirinya berbeda dengan orang biasa dan diperlakukan sebagai orang yang mendapat karunia sifat adikodrati, adimanusiawi atau kekuatan kualitas yang sangat luar biasa. Kharismatik adalah individu luar biasa yang berbeda dengan orang lain, ia menjadi teladan sebagai seorang pemimpin yang mempunyai pengikut serta mendapat pengakuan masyarakat.

Kharisma dapat dilihat dan diperhatikan dalam kenyataan kehidupan seharihari, berupa sesuatu yang erat hubungan dengan seseorang yang luar biasa. Bagi Weber kharisma memainkan peran yang sangat menonjol dalam kehidupan, sebagai hal yang luar biasa dan sumber perubahan pembaharuan. Kapasitas luar biasa untuk memperoleh pengikutnya dan menimbulkan rasa hormat. Dengan inilah figur kharismatik dihormati, diterima dan diikuti dengan sukarela. Kharisma melahirkan panggilan, dan mereka yang karena sebab apapun dapat mendengar panggilan ini akan menanggapinya dengan yakin. ${ }^{12}$

Tokoh-tokoh agama Dayak di Desa Kapul Kecamatan Halong Kabupaten Balangan mempunyai kedudukan yang tinggi di mata masyarakatnya dan sangat dihormati karena keilmuaanya, kekuataannya dan jabatannya. Teori kharismatik dari Max Weber bisa digunakan untuk melihat pengaruh kharismatik tokoh-tokoh agama Dayak di Desa Kapul Kecamatan Halong terhadap masyarakat Dayak yang tinggal di sekitarnya, baik ketika ia sedang memimpin acara keagamaan, mengatasi masalah yang terjadi di wilayahnya, dan memutuskan hukuman adat bagi yang melanggar hukum adat maupun dalam kehidupan sehari-hari.

\section{Gambaran Umum Desa Kapul Kecamatan Halong Kabupaten Balangan}

Ketika memasuki Desa Kapul, dari kejauhan sudah terlihat di pintu gerbangnya terdapat patung yang berbentuk manusia yang menandakan akan memasuki daerah kampung Dayak Kecamatan Halong Kabupaten Balangan. Desa Kapul terletak di wilayah Kecamatan Halong Kabupaten Balangan Propinsi Kalimantan Selatan. Desa ini memiliki luas 19,00 ha, 2,88\% dari luas Kecamatan

\footnotetext{
${ }^{11}$ Mirhan, K. H. Muhammad Zaini Abdul Ghani Di Martapura Kalimantan Selatan (19422005), (Banjarmasin: Antasari Press, 2012), 54-56.

${ }^{12}$ Mirhan, K. H. Muhammad Zaini Abdul Ghani Di Martapura Kalimantan Selatan (19422005), 18.
} 
Halong. Jarak tempuh ke kecamatan sekitar $20 \mathrm{~m}$, ke kabupaten sekitar $25 \mathrm{~km}$, dan ke propinsi sekitar $250 \mathrm{~km}$.

Desa Kapul termasuk dalam klasifikasi desa swasembada. Desa ini memiliki 4 Rukun Tetangga (RT), 3 tempat pendidikan (TK, TPA, SD) dan 2 tempat pengobatan seperti Poskesdes dan Posyandu.Berdasarkan data kependudukan Desa Kapul tahun 2014, penduduknya berjumlah 964 orang dengan kepala keluarga 177 orang. Mata pencaharian penduduk desa Kapul adalah sebagai petani, berdagang dan PNS.

Desa Kapul merupakan salah satu desa Suku Dayak yang ada di Kecamatan Halong. Merupakan desa yang di tempati oleh berbagai macam-macam agama, bahkan ada yang dalam satu rumah berbeda agama, seperti agama Islam, Hindu, Budha dan Kristen, dan agama Dayak Balangan. Ini bisa dilihat dari jumlah tempat ibadah Gereja 3 dan Wihara $1{ }^{13}$ Tetapi mereka bisa hidup rukun dan damai dalam kehidupan sehari-hari. Hal ini didasarkan karena pengaruh dari seorang pemimpin tokoh agama (Balian) mereka yang memiliki kekuasaan untuk memberikan peringatan dan membina mereka untuk saling menghargai satu sama lain, sehingga ketika bergaul di kehidupan sehari-hari mereka orang Dayak dan non Dayak tidak pernah menyinggung tentang keyakinan yang dimiliki.

Adanya keberagaman agama ini masyarakat Dayak Kapul tidak merasa terganggu dalam melaksanakan aktivitas sosial keagamaan mereka. Apapun kegiatan yang sudah menjadi turun-temurun dari nenek moyang mereka tetap berjalan dan tidak ada kendala misalnya, acara Arub Adat Babarin, dan Acara Menangkal Bala untuk kampung. ${ }^{14}$ Hal ini bisa dilihat ketika masyarakat Dayak yangberbeda agama dengan mereka mengadakan acara, (Islam, Kristen, Hindu dan Budha) mereka juga ikut membantu persiapan acara tersebut, karena mereka mempunyai prinsip awalnya mereka berasal dari satu nenek moyang. Dalam acara yang sakral masyarakat Dayak juga mengundang pihak pemerintah yang ada di Kecamatan Halong untuk menghadiri acara tersebut. Ini menandakan bahwa mereka juga menghargai aparat pemerintah yang ada di Kecamatan Halong. Namun, dalam acara tersebut sudah disediakan makanan yang khusus untuk para undangan yang beragama Islam. Jadi makanan untuk non-Muslim dan Muslim sudah dibedakan sejak awal. ${ }^{15}$

Salah satu sikap saling toleransi di Desa Kapul Kecamatan Halong terdapat dalam acara Pesona Dayak Meratus dengan tema: Ngetan Adat Lelubur Amak Nyembelum Banua. Acara Pesona Dayak Meratus ini merupakan acara tahunan yang diselenggarakan oleh pemerintah Kabupaten Balangan yang sudah berjalan dari tahun 2014 sampai sekarang. Selama tiga tahun berturut-turut Desa Kapul menjadi penyelenggara acara ini.

\footnotetext{
${ }^{13}$ Badan Pusat Statistik Kabupaten Balangan Bekerjasama dengan Bappeda Kabupaten Balangan, Kecamatan Halong Dalam Angka 2014,

${ }^{14}$ Ibas Balian Kapul, Wawancara Pribadi, 7 Maret 2017.
} 
Ngetan Adat Lelubur Amak Nyembelum Banua artinya mengingat adat leluhur untuk membagun banua, kegiatan ini diadakan dalam rangka menyambut HUT Kabupaten Balangan yang Ke 17 di Desa Kapul Kecamatan Halong Kabupaten Balangan. Dalam acara ini dapat disaksikan bagaimana rasa toleransi itu terlihat dengan jelas. Pluralitas agama itu tidak menjadikan penghalang dalam hubungan sosial. Dari hari pertama acara ini diselenggarakan warga Desa Kapul ini saling tolong-menolong baik yang berasal dari agama Islam, Kristen, Budha dan Hindu untuk gotong-royong dan mempersiapkan acara tersebut sampai acara ini selesai.

Tujuan acara ini untuk memperkenalkan kembali kepada masyarakat luas bahwa di Kecamatan Halong Kabupaten Balangan masih ada Suku Dayak bukan hanya sekedar kabar dan peninggalan sejarah. Dalam acara ini diadakan berbagai lomba seperti, menyumpit, bagasing, engrang dan menari tarian adat Dayak. Di acara ini juga ditampilkan kisah tokoh orang Dayak Halong yang memiliki ilmu kebal tahan terhadap senjata tajam dan duri.Acara ini juga dihadiri oleh perwakilan suku-suku Dayak yang berada di Propinsi Kalimantan Selatan misalnya dari, Suku Dayak Kabupaten Tapin dan Suku Dayak Loksado dari Kabupaten Hulu Sungai Selatan. Sedangkan tujuan pemerintah mengadakan acara ini adalah untuk menjadikan Suku Dayak dan Kampung Dayak ini menjadi objek wisata dan daya tarik wisatawan untuk berkunjung ke Kecamatan Halong Kabupaten Balangan. ${ }^{16}$

Dalam acara pembukaan dan penutupan dihadiri oleh pejabat pemerintah seperti bapak Bupati Kabupaten Balangan H. Ansharuddin, Kapolres Kabupaten Balangan, Kodim 101 Antasari Amuntai, Dinas Pariwisata dan Budaya Propinsi Kalimantan Selatan, Dewan Adat Dayak Propinsi Kalimantan Selatan, dan Dewan Adat Dayak Kabupaten Balangan. Selain itu, semua kepala adat yang berada di Kecamatan Halong dan tokoh-tokoh agama Kecamatan Halong seperti tokoh dari agama Budha, Hindu, Kristen, Islam, dan agama Dayak juga berhadir di acara ini, bahkan dalam prosesi pelaksanaannya, digunakan empat macam bacaan doa yang berbeda dari masing-masing agama ketika waktunya berdoa, tidak ketinggalan para wartawan surat kabar baikdan televisi baik lokal maupun nasional datang untuk meliput acara tersebut. Betapa mereka sangat menghargai pluralitas agama yang ada di desa Kapul ini. ${ }^{17}$

\section{Pluralitas Agama Menurut Tokoh-Tokoh Agama Dayak di Desa Kapul Kecamatan Halong Kabupaten Balangan.}

Agama bagi para pemeluknya merupakan sesuatu yang luhur dan diyakini dapat membawa keselamatan hidup didunia dan di alam setelah ia mati, yang dapat membawa dirinya ke jalan Tuhan. Agama bagi para pemeluknya merupakan

\footnotetext{
${ }^{16}$ Juhri A Balian desa Liyu, Wawancara Pribadi, 5 Maret 2017.

${ }^{17}$ Wawancara dengan Juhri A selaku Damang yang bertugas di kantor Kemenag Kabupaten Balangan sekaligus kepada adat desa Liyu. Kata damang sebenarnya merupakan kepala adat akan tetapi karena berada di bawah pemerintahan jadi sebutannya Damang, 5 Maret 2017.
} 
kebutuhan yang niscaya, yang seringkali sangat menentukan dalam kehidupannya, lebih dari pada yang lainnya. Dalam konteks ini agama dijadikan sebagai desain bagi kehidupan para pemeluknya.

Agama digunakan oleh para pemeluknya sebagai pandangan hidup yang menjelaskan keberadaan manusia di dunia, sehingga agama merupakan satu-satunya kebudayaan yang menjelaskan arah dan tujuan hidup. Agama tidak hanya mengatur hubungan manusia dengan Tuhan, tetapi juga mengatur hubungan manusia dengan manusia lainnya. Berarti, agama jugaterkait erat dengan aspek-aspek kehidupan masyarakat seperti, kekarabatan, kepemimpinan, politik,ekonomi, dan sebagainya. ${ }^{18}$

Menurut M. Reville agama merupakan daya penentu kehidupan manusia, yaitu sebuah ikatan yang menyatukan pikiran manusia dengan pikiran misterius yang menguasai dunia dan diri yang dia sadari, dan hal-hal yang menimbulkan ketentraman bila terikat dengan hal tersebut. Sedangkan Menurut Taylor dalam mempelajari agama-agama masyarakat ras terkebelakang, hal pertama yang harus dilakukan adalah mendefinisikan dan menentukan apa yang dimaksudkan seseorang dengan agama. Jika seseorang menyatakan bahwa istilah agama berarti kepercayaan terhadap sesuatu yang tinggi dan agung. Maka suku-suku tertentu tidak akan masuk ke dalam dunia agama yang ditentukan dengan definisi ini. Oleh karena itu akan lebih baik memakai sesuatu yang spiritual sebagai definisi minimum untuk agama. Oleh karena itu, apaapa yang dikenal sebagai arwah orang mati, jin, setan dan dewa-dewi masuk ke dalam definisi tersebut. ${ }^{19}$

Di desa Kapul ini memang memiliki berbagai macam agama baik yang berasal dari langit (Islam, Kristen dan Yahudi) maupun yang berasal dari buatan tangan manusia (Hindu, Budha, Konghuchu dan agama nenek moyang). ${ }^{20}$ Hidup berdampingan dengan berbagai macam-macam agama memang terasa sulit awalnya. Namun, lama-kelamaan sudah menjadi hal yang biasa bahkan ketika ada kegiatankegiatan yang dilaksanakan oleh salah satu agama, penganut agama yang lain akan membantu persiapan acara dari awal sampai berakhir acara, mereka juga mengundang penganut agama lain untuk hadir dalam acara tersebut. ${ }^{21}$ Seorang tokoh agama Dayak mengatakan sangat menghormati dengan pemeluk agama yang lainnya. Ketika acara hari raya salah satu agama,merekaselaku orang Dayak juga ikut mengahadiri undangan yang berasal dari agama lain seperti hari raya dalam agama Islam, Hindu dan Kristen Katolik, kegiatan-kegiatan yang bernuansa agama dan sosial seperti, acara perkawinan dan acara kematian. Karena menurut pendapat mereka, mereka awalnya berasal dari nenek moyang yang sama, jadi mereka masih memiliki hubungan kekeluargaan walaupun sudah memeluk agama yang berbeda.

${ }^{18}$ Haedar Nashir, Agama dan Kemanusian Modern, (Yogyakarta: Pustaka Pelajar, 1999), 102-103.

${ }^{19}$ Emile Durkheim, The Elementary Forms of the Religius Life, terj Inyiak Ridwan Muzir, (Yogyakarta: IRCiSoD, 2003), 56.

${ }^{20}$ Awes Balian Ha,uwai, Wawancara Pribadi, 7 Maret 2017.

${ }^{21}$ Guru Madarasah Aliyah Halong, Wawancara Pribadi, Halong, 25 Febuari 2017. 
Negara wajib untuk menjamin kondisi-kondisi sosial agar agama-agama dapat hidup dan berkembang, dilain pihak untuk menghormati kebebasan beragama. Kebebasan beragama mempunyai dua sisi, pertama hak setiap orang untuk hidup sesuai dengan keyakinan- keyakinannya dan kebebasan agama-agama untuk mengurus dirinya sendiri. Segi pertama dapat dirumuskan sebagai berikut, karena agama dan kepercayaan terhadap Tuhan Yang Maha Esa berdasarkan keyakinan, maka tidak dapat dipaksakan dan memang agama dan kepercayaan terhadap Tuhan Yang Maha Esa itu tidak memaksa setiap manusia untuk memeluk dan menganutnya. Kebebasan agama adalah merupakan salah satu hak yang paling asasi diantara hak-hak asasi manusia, karena kebebasan kebebasan beragama itu langsung bersumber kepada martabat manusia sebagai makhluk ciptaan Tuhan. Kebebasan agama bukan pemberian negara atau pemberian golongan.

Hak dan kebebasan beragama serta berkeyakinan merupakan salah satu hak asasi manusia yang bersifat mutlak sebagai wujud dari hak asasi manusia yang paling inti. Karena itu sering dikatakan bahwa, hak dan kebebasan beragama merupakan hak asasi yang bersifat non-derogable rights yaitu hak asasi manusia (HAM) yang tidak dapat dikurangi dalam keadaan apapun. Hal ini sesuai dengan peraturan Pancasila, sila I, berbunyi "Ketuhanan Yang Maha Esa" dan Undang-Undang Dasar 1945. Pasal 28 I, ayat 1, menyatakan bahwa, hak untuk hidup, hak untuk tidak disiksa, hak kemerdekaan pikiran dan hati nurani, hak beragama, hak untuk tidak diperbudak, hak untuk diakui sebagai pribadi di hadapan hukum, dan hak untuk tidak dituntut atas dasar hukum yang berlaku surut adalah hak asasi manusia yang tidak dapat dikurangi dalam keadaan apa pun. Dan pasal 29 ayat (2) bahwa,Negara menjamin kemerdekaan tiap-tiap penduduk untuk memeluk agamanya masing-masing dan untuk beribadat menurut agamanya dan kepercayaannya itu. ${ }^{22}$

Seorang tokoh agama Dayak berpendapat bahwa memeluk agama itu merupakan keinginan masing-masing menurut kenyakinannya. Bahkan dalam agama nenek moyang mereka (Dayak) banyak yang memilih untuk memeluk agama yang berbeda-beda bahkan dalam satu rumah bisa terdapat bermacam-macam agama. ${ }^{23}$ Saya tidak mau berpisah dengan keluarga saya hanya karena agama yang kami yakini berbeda. Demkian pernyataan yang sering disampaikan oleh para tokoh adat di daerah-daerah yang menganut agama dan adat yang taat. ${ }^{24}$

Pluralitas agama yang ada di Desa Kapul Kecamatan Halong Kabupaten Balangan sudah ada sejak zaman dahulu kala sebelum terbentuknya Kabupaten Balangan. Mereka sudah menganggap pluralitas agama itu bukan sebagai penghalang untuk menjalankan ibadah dan beragama menurut keyakinan masing-masing, tidak menjadikan mereka untuk saling bertengkar dengan mengatas namakan agama seperti

${ }^{22}$ Hairus Salim HS dan Suhadi, Membangun Prluralisme Dari Bawah, (Yogyakarta: Lembaga Kajian Islam dan Sosial, 2007), 89-90.

${ }^{23}$ Gupen Balian Aniungan, Wawancara Pribadi, 7 Maret 2017.

${ }^{24}$ Syahrin Harahap, Teologi Kerukunan, (Jakarta: Prenada Media Group, 2011), 9-11. 
yang sering terjadi di daerah Indonesia lainnya. Adanya pluralitas agama ini menjadikan desa ini sebagai percontohan untuk desa-desa yang ada di Kecamatan Halong yang sudah diprogramkan oleh pemerintah melalui Forum Kerukunan Umat Beragama (FKUB) lebih khusus untuk di Kabupaten Balangan. Di desa ini memang memiliki berbagai macam agama, seperti agama Islam, Kristen Katolik, Hindu, Budha, dan agama lokal, tetapi mereka bisa hidup dengan rukun dan damai, ini tidak terlepas dari pengaruh dan peran seorang tokoh agama yang mempunyai nilai kharismatik di mata pengikut agamanya yang bisa mengarahkan dan membina mereka untuk taat dalam beribadah. Sehingga hubungan sosial mereka tetap terjaga, baik dengan sesama pemeluk agama, dengan pemeluk agama lain dan dengan pihak pemerintah.

\section{Penutup}

Pluralitas agama atau kemajemukan agama adalah kondisi yang tidak dapat ditolak oleh manusia. Satu hal yang perlu dilakukan adalah bagaimana menyikapi kemajemukan tersebut. Sejauh ini tercatat beberapa sikap yang digunakan oleh para pemeluk agama dalam menyikapi agama lain di antaranya adalah pluralitas. Model kemajemukan muncul sebagai sikap yang dipandang sesuai untuk merespon kemajemukan agama.Pluralitas agamabagi tokohtokoh agama Dayak di Desa Kapul Kecamatan Halong Kabupaten Balangan berarti memeluk agama itu kembali pada keinginan masingmasing. Masyarakat Dayak malah banyak yang memilih memeluk agama yang berbeda dari para tokoh-tokohnya. Adapun para tokohnya menghormati keputusan mereka. Peran tokoh agama sebagai teladan dalam bertoleransi menjadikan masyarakat di sana yang walaupun berbeda agama kerap kali turut berpartisipasi dalam kegiatan keagamaan umat lain karena pada dasarnya masyarakatnya menganggap bahwa mereka berasal dari satu leluhur dan agama tidak akan pernah membatasinya.

\section{DAFTAR PUSTAKA}

Badan Pusat Statistik Kabupaten Balangan Bekerjasama dengan Bappeda Kabupaten Balangan, Kecamatan Halong Dalam Angka 2014.

Durkheim, Emile, The Elementary Forms of the Religius Life, terj Inyiak Ridwan Muzir, Yogyakarta: IRCiSoD, 2003. 
Fawaizul, Mustain, Umam, Pluralisme Pendidikan Agama Hubungan Muslim-Hindu di Lombok. Mataram: LKM IAIN Mataram, 2005.

Harahap, Syahrin, Teologi Kerukunan, Jakarta: Prenada Media Group, 2011.

Husein, Muhammad, Mengaji Pluralisme Kepada Mahaguru Pencerahan, Bandung: Mizan, 2011.

Ismail, Faisal, Dinamika Kerukunan Antarumat Beragama, Bandung: PT Remaja Rosdakarya, 2014.

Kementerian Agama Data Penganut Agama Kabupaten Balangan akhir tahun 2015.

Malik, Anis Thoha, Tren Pluralisme Agama Tinjauan Kritis, Jakarta: Perspektif, 2005.

Nashir, Haedar, Agama dan Kemanusian Modern, Yogyakarta: Pustaka Pelajar, 1999.

Nur Kholis M, Setiawan dan Djaka Soetap, Meniti Kalam Kerukunan. Jakarta: PT BPK Gunung Mulia, 2010.

Salim HS, Hairus dan Suhadi, Membangun Prluralisme Dari Bawah, Yogyakarta: Lembaga Kajian Islam dan Sosial, 2007.

Sumbulah, Umi, Nurjannah, Pluralisme Agama Makna dan Lokalitas Pola Kerukunan Antarumat Beragama, Malang: UIN Maliki Press, 2013.

Tobroni, Relasi Kemanusian dalam Beragama Mengembangkan Etika Sosial Melalui Pendidikan). Bandung, Karya Putra Darwati, 2012.

Muslich, M, Adnan Qohar, Nilai Universal Agama-Agama Di Indonesia: Munuju Indonesia Damai, Yogyakarta: Kaukaba, 2013.

Zainuddin,M. Pluralisme Agama Pergulatan Dialogis Islam-Kristen di Indonesia, Malang: UIN Maliki Press, 2013. 